ORIGINAL ARTICLE

AFRICAN JOURNAL OF CLINICAL AND EXPERIMENTAL MICROBIOLOGY. MAY 2014 ISBN 1595-689X VOL15 No.2

AJCEM/1413

COPYRIGHT 2014 http://dx.doi.org/10.4314/ajcem.v15i2.5

http://www.ajol.info/journals/ajcem

AFR. J. CLN. EXPER. MICROBIOL. 15(2): 84-90

\title{
CANDIDURIA AMONG HIV- INFECTED PATIENTS ATTENDING A TERTIARY HOSPITAL IN BENIN CITY
}

Esebelahie, N. O. ${ }^{*} 1,3$ Enweani, I. B.,1 Newton-Esebelahie, F. O.,2,3 Omoregie, R3

1. Department of Medical Laboratory Science, Faculty of Health Sciences and Technology, College of Health Sciences,

Nnamdi Azikiwe University, Nnewi Campus, Nnewi, Anambra State, Nigeria; 2. Department of Medical Laboratory Sciences, School of Basic Medical Science, University of Benin, Benin City, Edo State, Nigeria; 3. School of Medical Laboratory Sciences, University of Benin Teaching Hospital, P.M.B. 1111, Benin City, Edo State, Nigeria.

*Correspondence: E-mail: newtonesebelahie@yahoo.comTel: +2348037941446

\begin{abstract}
Background: Candiduria is a common finding. However, in immunocompromised patients like HIV-infected individuals, it has high risk of morbidity and mortality as it could be a pointer to systemic candidiasis. Unfortunately, there are no clear criteria for differentiating between colonization and infection or between upper or lower urinary tract infections.

Objective: This study focused on determining the spectrum of Candida species implicated in candiduria among HIV-infected individuals and their susceptibility to fluconazole and voriconazole in a tertiary hospital.Methods: A total of 300 subjects comprising of $200 \mathrm{HIV}$ patients and 100 nonHIV individuals were used for this study. Clean catch midstream were collected from each individual and processed using standard microbiological techniques. Emergent Candida isolates were identified with CHROMagar Candida and sugar fermentation tests. Results: The overall prevalence of candiduria among HIV patients was $13.5 \%$. HAART-naive patients had a significantly higher prevalence $(\mathrm{OR}=4.165,95 \% \mathrm{CI}=1.602,10.828$; $\mathrm{P}=0.0038)$ than their counterpart on highly active antiretroviral therapy (HAART). Female gender was a significant risk factor for acquiring candiduria. Age had no significant effect on the prevalence of candiduria in this study. A CD4+ count $<200$ cells/ $\mu 1$ was a significant risk factor for acquiring candiduria only among HAART-naive patients $(\mathrm{OR}=11.711 ; 95 \% \mathrm{CI}=3.943,34.780 ; \mathrm{P}=0.0001)$. The three species of $\mathrm{Candida}$ recovered from this study were C. albicans, C. krusei and C.parapsilosis. C. albicans $(64.52 \%, 83.36 \%)$ and C. krusei $(66.67 \%, 100.00 \%)$ were resistant to fluconazole and voriconazole respectively.Conclusion: There is a significant relationship between antiretroviral therapy, CD4+ counts, and the prevalence of candiduria among the study population.
\end{abstract}

Keywords:HAART, HAART-naive, candiduria, CD4+ counts, Candida, prevalence.

\section{CANDIDURIE CHEZ DES MALADES VIVANT AVEC LE VIH DANS UN HOPITAL TERTIAIRE DANS LA VILLE DE BENIN}

Esebelahie, NO*1,3 Enweani, IB,1 Newton-Esebelahie, FO,2,3 Omoregie, R3

1Département de Science de Laboratoire Médical , Faculté des Sciences de la Santé et de la Technologie, Collège des Sciences de la Santé, Université de Nnamdi Azikiwe , Campus de Nnewi , Nnewi , Etat d'Anambra , Nigéria.

2Département de Sciences de Laboratoire Médical, École des Sciences de Base de Médecine, Université du Bénin,Ville de Bénin, État d'Edo, Nigeria ; 3 École de Sciences de Laboratoire Médical, Centre Hospitalier Universitaire de Bénin, BP 1111, Ville du Bénin, Etat d'Edo, Nigeria

*Adresse Mail d'auteur correspondant: E -mail : newtonesebelahie@yahoo.comTel : +2348037941446

RÉSUMÉ

Contexte: La candidurie est un problème commun de sante publique. Cependant, chez les patients immunodéprimés comme les individus infectés par le VIH, elle présente un risque élevé de morbidité puisqu'elle peut évoluer vers la candidose systémique.

Malheureusement, il n'existe pas de critères clairs permettant de distinguer la colonisation et l'infection de même que les infections des voies urinaires supérieures et inférieures.

Objectif: Cette étude a porté sur la détermination du spectre d'espèces de Candida impliqués dans la candidurie chez les personnes infectées par le VIH et leur sensibilité au fluconazole et voriconazole dans un hôpital tertiaire. Methodes : Un total de 300 sujets comprenant 200 patients atteints du VIH et 100 personnes non -VIH ont été utilisés dans cette étude. Les echantillons d'urine ont été collectées auprès de chaque personne par la methode de "Clean catch midstream"et traitées en utilisant des techniques microbiologiques standard. Les isolats émergents de Candida ont été identifiés avec CHROMagar Candida et les tests de fermentation de sucre. Résultats : La prévalence globale du VIH chez les patients atteints de candidurie était de $13,5 \%$. Les patients en naïfs de la multithérapie HAARTavaient une prévalence significativement plus élevée $(\mathrm{OR}=4,165, \mathrm{IC}$ à $95 \%=$ 
$1,602,10,828, p=0,0038$ ) par rapport a leurs homologues sous traitement antirétroviral hautement actif (HAART ) . Le sexe féminin était un facteur de risque important d'acquisition de candidurie. L'âge n'avait pas d'effet significatif sur la prévalence de candidurie dans cette étude. Un compte de CD4 $+<200$ cellules / $\mu 1$ n'a été un facteur de risque important pour l'acquisition de candidurie que chez les patients en multithérapie naïfs $(\mathrm{OR}=11,711 ; \mathrm{IC}$ à $95 \%=3,943,34,780, p=0,0001)$. Les trois espèces de Candida récupérés de cette étude étaient $C$. albicans, $C$. krusei et $C$.parapsilosis. C. albicans $(64,52 \%, 83,36 \%)$ et $C$. krusei $(66,67 \%, 100,00 \%)$ étaient résistants respectivement au fluconazole et voriconazole. Conclusion: Il existe une relation significative entre le traitement antirétroviral, CD4 +, et la prévalence de candidurie parmi la population de l'étude.

Mots-clés: multithérapie HAART , naïs , candidurie , CD4 + , Candida , prévalence .

\section{INTRODUCTION}

Acquired immunodeficiency syndrome (AIDS) cause by human immunodeficiency virus (HIV) is the most important public health problem of modern times (1). $\mathrm{HIV} / \mathrm{AIDS}$ continues to spread globally and remains a worldwide pandemic affecting about 40 million people (2). The pandemic is the leading cause of death in sub-Sahara Africa and the fourth leading cause of mortality worldwide and over $95 \%$ of these deaths have occurred among young adults in the developing world (3-4).

Fungal infections caused by yeast pathogens remain quite common in immunocompromised host, especially in HIV-infected individuals (5). These infections are playing an increasing important role in the morbidity and mortality of HIV/AIDS patients (6). Although the use of highly active antiretroviral therapy (HAART) has decreased the incidence of fungal infections (7-8), candidiasis continues to afflict HIV-infected individuals in HAART era $(6,9)$. Unfortunately, prolong use of antifungal among this population has led to increased incidence of resistance (10).

The healthy urinary tract is sterile so the presence of Candidaspecies in urine or candiduria represent a variety of clinical situations (11-13), such as contamination of urine specimen, colonization of bladder due to indwelling catheters, infection of upper or lower urinary tract, and primary or disseminated candidiasis (13-15).

Candidaspecies are the most commonly recovered fungi from urine (16) with $\mathrm{C}$. albicans being the most frequently isolated, accounting for $50-70 \%$ of isolates in various studies $(15,17)$. Others non-albicans such as C. glabrata and C. tropicalis are the next most common species while $C$. parapsilosis is commonly found in urine of neonates and is usually associated with systemic infection in this population (18).

Conditions that predispose to candiduria includes immunosuppresion, use of broad spectrum antibiotic, gender, age, diabeties mellitus, chronic renal failure, malignancy, urinary tract abnormalities, pregnancy, and neutropenia $(16,19-23)$.
Asymptomatic candiduria is usually benign in most patients and do not require antifungal medication (24). However, in immunocompromised patients, it has a high risk of morbidity and mortality (25). There is little or no report on candiduria among HIVinfected individuals in our locality, thus this study focused on determining the spectrum of Candida species implicated in candiduria among HIV-infected individuals and their susceptibility to fluconazole and voriconazole.

\section{MATERIALS AND METHODS Study Area}

The study was carried out in the University of Benin Teaching Hospital, Benin City, Nigeria. It is located in the South-South geopolitical zone of Nigeria. It serves as a referral hospital to about six to ten states in Nigeria. It is a centre for Institute of Human Virology, Nigeria and US President's Emergency Plan for AIDS Relief (PEPFAR) HIV/AIDS interventions in the zone.

\section{Study Population}

A total of 300 individuals consisting of $200 \mathrm{HIV}$ patients and 100 (42 males and 58 females) apparently healthy, aged-matched, non-HIV individuals were recruited for this study. The patients consists of 100 (31 males and 69 females) HAART-naïve patients and 100 (22males and 78 females) HIV patients on HAART for 3-6 months. The HAART regimen included stavudine, zidovudine, and nevirapine. The HIV patients were out-patients and asymptomatic. Informed consent was obtained from all individuals prior to specimen collection. The Ethical Committee of the University of Benin Teaching Hospital approved the protocol for this study.

\section{Specimen collection and processing}

Venous blood $(5 \mathrm{ml})$ was collected into ethylene diamine tetraacetic acid (EDTA) container and mixed. Clean-catch mid-stream urine was collected into sterile universal container containing few crystals of boric acid as preservative (26).

The blood specimens were used for CD4 counts using flow cytometry (Partec, Germany) following 
manufacturer's instruction. A loop-full $(0.001 \mathrm{ml})$ of well mixed un-centrifuged urine was streaked onto

the surface of Saboraund's Dextrose Agar (SDA) and Brain Heart Infusion Agar (BHIA) containing $5 \mu \mathrm{g} / \mathrm{ml}$ gentamicin. The plates were incubated aerobically at 370C for 24-48 hours and counts were expressed in colony forming unit per $\mathrm{ml}$. A count of $\geq 105 \mathrm{cfu} / \mathrm{ml}$ was considered significant to indicate asymptomatic candiduria. The urine specimens were centrifuged at $2000 \mathrm{~g}$ for 5 minutes. The supernatant was discarded and a drop of the deposit was examined microscopically at high magnification for pus cells. Pus cells $\geq 5$ per high power field were considered to indicate infection (26).

Emergent yeast colonies were stored for identification. All Candida isolates were identified with CHROMagarTMCandida (Paris, France) as previously described (27) and sugar fermentation tests as described by Forbes et al., (28).Antifungal susceptibility test was performed using the CLSI (29) disc diffusion methods. Voriconazole disc $(1 \mu \mathrm{g})$ and

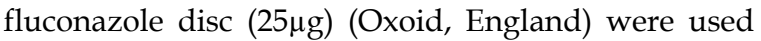
for this study.

\section{RESULTS}

The prevalence of candiduria among HIV and nonHIV individuals is shown in table 1 . HIV status was a significant risk factor for acquiring candiduria (OR=3.746; $\quad 95 \% \mathrm{CI}=1.273, \quad 11.025 ; \quad \mathrm{P}=0.0189)$. Considering HIV status, the prevalence of candiduria among HAART-naïve patients was significantly higher than HIV patients on HAART $(\mathrm{P}=0.0038)$. Female gender was significantly associated with candiduria.

TABLE 1: PREVALENCE OF CANDIDURIA AMONG HIV AND NON-HIV INDIVIDUALS.

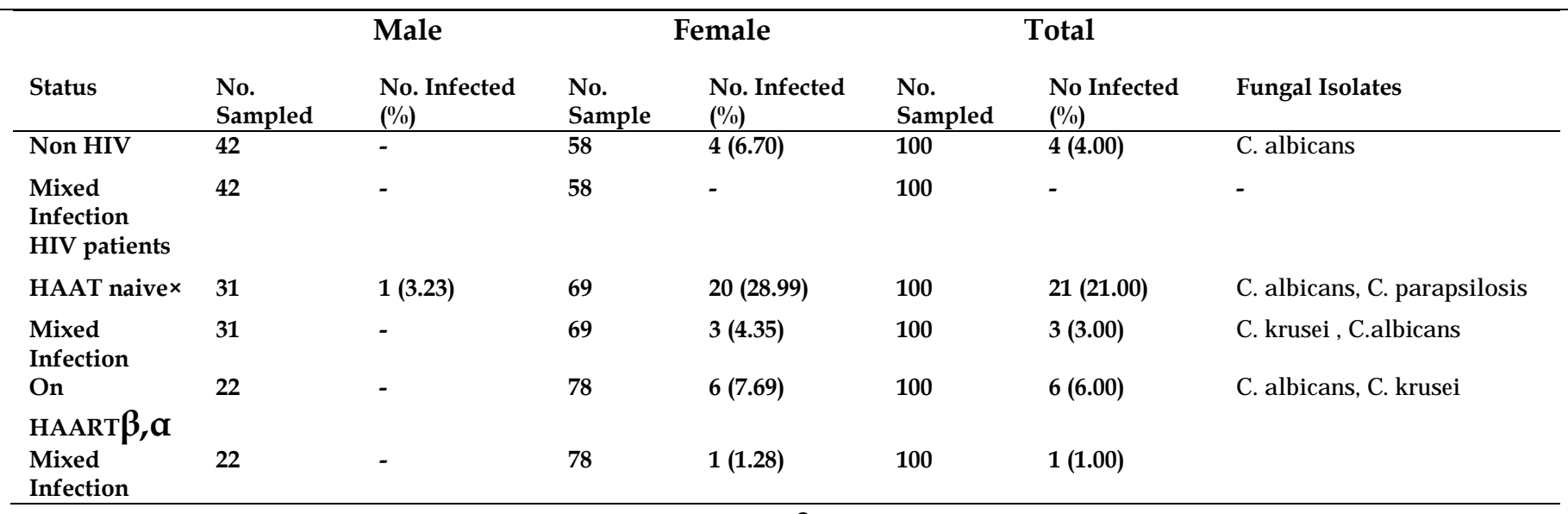

HIV versus non-HIV: $O R=3.746 ; 95 \% C I=1.273,11.025 ; \mathrm{P}=0.0189$; $\beta$ On HAART versus non-HIV: $\mathrm{OR}=1.532 ; 95 \% \mathrm{CI}=0.4187,5.604$;

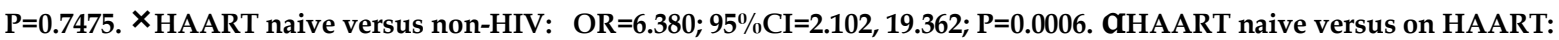
$\mathrm{OR}=4.165,95 \% \mathrm{CI}=1.602,10.828 ; \mathrm{P}=0.0038$

Only one male among HAART-naive HIV patient had candiduria. The prevalence of candiduria did not differ significantly $(\mathrm{P}=0.7475)$ between HIV patients on HAART and non-HIV individuals.

Table 2 show Candida isolates recovered from HIV and non-HIV individuals. $C$. albicans was still the most prevalent and the only isolate recovered from non-HIV individuals. C. krusei was recovered from HIV patients on HAART and HAART-naïve while $C$. parapsilosis were recovered only from HAART-naïve HIV patients. 
TABLE 2: CANDIDA ISOLATES RECOVERED FROM URINE OF HIV AND NON-HIV INDIVIDUALS

\begin{tabular}{lllll}
\hline Organisms & Non-HIV (\%) & HAART-naïve (\%) & On HAART (\%) \\
\hline C. albicans & $4(100.00)$ & $20(86.96)$ & $7(87.50)$ & Total (\%) \\
C. krusei & - & $2(8.70)$ & $1(12.50)$ & $3(88.57)$ \\
C. Parapsilosis & - & $1(4.45)$ & - & $1(2.86)$ \\
\hline
\end{tabular}

TABLE 3: CANDIDA ISOLATES RECOVERED FROM URINE OF HIV AND NON-HIV INDIVIDUALS IN RELATION TO GENDER

\begin{tabular}{lllllllll}
\hline Organisms & \multicolumn{2}{c}{ Non-HIV } & \multicolumn{2}{c}{ HAART-naive } & \multicolumn{2}{c}{ On HAART } & \\
& Male (\%) & Female (\%) & Male (\%) & Female (\%) & Male (\%) & Female (\%) & Male (\%) & Female (\%) \\
\hline C. albicans & - & $4(100.00)$ & $1(100.00)$ & $19(82.61)$ & $4(80.00)$ & $7(87.50)$ & $1(100.00)$ & $30(85.71)$ \\
C. krusei & - & - & - & $2(8.70)$ & - & $1(12.50)$ & - & $3(8.52)$ \\
C. parapsilosis & - & - & - & $1(4.35)$ & - & - & - & $1(2.86)$ \\
\hline
\end{tabular}

Table 3 show Candida isolates recovered from HIV and non-HIV individuals in relation to gender.
All C. albicans recovered from non-HIV individuals were from female. Similarly, C. krusei, and C. parapsilosis were recovered from female HIV patients.

TABLE 4: PREVALENCE OF CANDIDURIA AMONG HIV AND NON-HIV INDIVIDUALS IN RELATION TO AGE

\begin{tabular}{|c|c|c|c|c|c|c|}
\hline \multirow{2}{*}{$\begin{array}{l}\text { Age } \\
\text { Years }\end{array}$} & \multicolumn{2}{|c|}{ Non-HIV } & \multicolumn{2}{|c|}{ HAART-naive } & \multicolumn{2}{|c|}{ On HAART } \\
\hline & No. sampled & No. infected (\%) & No. sampled & No. infected $(\%)$ & No. sampled & No. infected $(\%)$ \\
\hline $11-20$ & 5 & - & - & - & - & - \\
\hline $21-30$ & 40 & $2(5.0)$ & 15 & $2(13.3)$ & 14 & - \\
\hline $41-50$ & 17 & 1 (5.9) & 32 & 5 (15.6) & 29 & $2(6.9)$ \\
\hline $51-60$ & 3 & - & 4 & $1(25.0)$ & 7 & 1 (14.3) \\
\hline $61-70$ & 1 & - & 1 & - & 3 & - \\
\hline
\end{tabular}

Non-HIV; P=0.9810; HAART-naïve; P=0.4160; On HAART; P=0.7329

TABLE 5. EFFECT OF CD4 COUNTS ON PREVALENCE OF CANDIDURIA AMONG HIV INDIVIDUALS

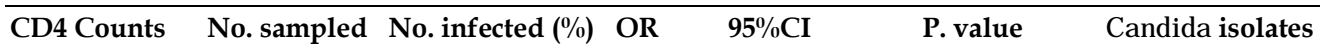

(Cells/ $\mu \mathrm{l})$

HAART naïve

$\begin{array}{lllllll}<200 & 32 & 17(53.13) & 11.711 & 3.943,34.780 & 0.0001 & \text { C. albicans } \\ \geq 200 & 68 & 6(8.82) & 0.085 & 0.029,0.254 & & \text { C. albicans, C. parapsilosis }\end{array}$

Mixed Infection

$\begin{array}{lllllll}<200 & 32 & 4(12.50) & 21.632 & 1.127,415.35 & 0.0152 & \text { C. albicans, C. krusei, } \\ \geq 200 & 68 & - & 0.046 & 0.002,0.888 & \end{array}$

On HAART

$\begin{array}{lllllll}<200 & 12 & 2(16.67) & 3.320 & 0.567,19.426 & 0.4260 & \text { C. albicans } \\ \geq 200 & 88 & 5(5.68) & 0.301 & 0.052,1.762 & & \text { C. albicans }\end{array}$

Mixed Infection

\begin{tabular}{lrrrrrrr}
$<200$ & 12 & $1(8.33)$ & 23.087 & $0.886,601.310$ & 0.2399 & C. albicans, C. krusei \\
& & & & & & & \\
$\geq 200$ & 88 & - & 0.043 & $0.002,1.128$ & & \\
\hline
\end{tabular}


Age had no significant effect on the prevalence of candiduria in this study (Table 4).

CD4 <200cells/ $\mu$ l was significantly associated with candiduria. However, among HIV patients on HAART, CD4<200cells/ $\mu$ l did not significantly affect the prevalence of candiduria (Table 5).
Among the yeasts recovered, more $\mathrm{C}$. albicans and $\mathrm{C}$. krusei were resistant to fluconazole and voriconazole. The only isolate of C. parapsilosis was susceptible to both antifungal agents (Table 6).

\section{TABLE 6: ANTIFUNGAL SUSCEPTIBILITY PROFILE OF CANDIDA ISOLATES}

\begin{tabular}{cccccccc}
\hline \multicolumn{2}{c}{ Organisms } & \multicolumn{3}{c}{ FLUCONAZOLE } & \multicolumn{3}{c}{ VORICONAZOLE } \\
& S (\%) & S-DD (\%) & R (\%) & S (\%) & S-DD (\%) & R (\%) \\
\hline C. albicans & $9(29.03)$ & $2(6.45)$ & $20(64.52)$ & $10(90.91)$ & $2(100.00)$ & $19(83.36)$ \\
C. krusei & $1(33.33)$ & - & $2(66.67)$ & - & - & $3(100.00)$ \\
C. parapsilosis $1(100.00)$ & - & - & $1(100.00)$ & - & - & \\
\hline
\end{tabular}

\section{DISCUSSION}

Fungal infections are playing an increasing important role in the morbidity and mortality of HIV/AIDS patients (6). Although the use of highly active antiretroviral therapy (HAART) has decreased the incidence of fungal infections (7-8), candidiasis continues to afflict HIV-infected individuals in HAART era $(6,9)$.

Recent studies have shown that candiduria is getting increased due to immunocompromised patients; prolong hospitalization, uncontrolled use of antibiotic, prophylaxis by antifungal agents, urinary tract surgeries $(11,30-31)$. Candiduria accounted for up to $10 \%$ of UTIs and has resulted in increased rate of mortality during the last decades due to use of new treatments, surgery and transplantation (14, 32-33).

In this study, the overall prevalence of candiduria among HIV-infected individual was $13.5 \%$. This is lower than 22\% reported in Brazil among hospitalized patients (35). HIV status was significantly associated with candiduria $(\mathrm{OR}=3.746 ; 95 \% \mathrm{CI}=1.273,11.025$; $\mathrm{P}=0.0189$ ). HIV results in immunosuppression which has been reported as a risk factor for acquiring candiduria (11). However, in regard to treatment status, the prevalence of candiduria among HIV patients on HAART (6\%) have no significant different with non-HIV (4\%) individuals. This indicates that candiduria in HAART-naïve HIV patients contributed to the significant difference in prevalence among HIV and non-HIV individuals. Thus as, HAART improves immunity, candiduria decreases to almost the same prevalence with that of non-HIV individuals.
Candida albicans $(88.57 \%)$ was the most predominant isolate recovered. This agrees with the report of previous investigators $(11,16,24)$. Other species of Candida recovered includes C.krusei $(8.57 \%)$ and C. parapsilosis $(2.86 \%)$. These species of Candida have previously been reported as causes of candiduria (16, 35).Irrespective of HIV status and treatment status, the female gender was associated with candiduria in this study. This is in agreement with the report of previous investigators $(14,19,22)$.In this study, increased age had no significant effect on the prevalence of candiduria. This does not agree with the report of Kauffman, (14). The reason for this is unclear.

Among HAART-naïve HIV patients, CD4<200cells/ $\mu$ l was associated with candiduria (Table 5). It has been reported that fungal agents such as Candida takes advantage of the immune suppression seen in HIV among HIV patients as a result of CD4 T cells depletion (35). This may explain the findings in this study. It has also been reported from a number of experimental studies that acquired resistant to Candida infection is dependent upon the participation of T-lymphocytes (35). HAART causes a decline in the incidence of some opportunistic infection in AIDS and this decline is currently attributed to restoration of immunity and anti Candida activity of protease inhibitors among the HAART regimen (35). This may explain the non significant difference in the prevalence of candiduria among HIV patients on HAART with CD4<200cells/ $\mu$ l and CD4 $\geq 200$ cells/ $\mu 1$. However, protease inhibitors were not among the HAART regimen for our HIV patients on HAART. This may therefore indicate that immune 
reconstitution may account for the observed results among HIV patients on HAART in relation to candiduria.Most of C. albicans $(64.52 \%, 83.36 \%)$ and C. krusei $(66.67 \%, 100.00 \%)$ were resistant to fluconazole and voriconazole respectively. It has been reported that Candida species from HIV patients are more resistant to antifungal agents (36-37). Prolong used of antifungal among HIV patients has been reported as predisposing factor (10).

\section{REFERENCES}

1. Rosen MJ. Pneumonia in patients with HIV infection. Med Clin North Am 1994; 78:106778

2. Maplanka CC. AIDS: is there an answer to the global pandemic? The immune system in HIV infection and control. Viral Immunol 2007; 20: 331-42.

4 Guattelli JC, Siliciano RF, Kuritzes DR, Richman, DD. Human immunodefiency virus. In: Clinical Virology. 2nd ed. ASM Press, 1752 N.st NW, Washington, D.C. 20036 - 2094, USA; 2002. p. 685-729.

5 UNAIDS (2008): Report on global AIDS epidemic (Downloaded August 14, 2010). From:http:/ / www.unaids.org/en/dataanal ysis/knowyourepidemic/epidemiologypubl ications/2008reportontheglobalaidsepidemic

6 Sanglard D. Clinical relevance of mechanisms of antifungal drug resistance in yeasts. Enferrm Infecc Microbiol Clin 2002; 20(9):462-70.

7 Yongabi KA, Mbacham WF, Nubia KK, Singh RM. Yeast strains isolated from HIVseropositive patients in Cameroon and their sensitivity to extracts of eight plants. Afr J Microbiol Res 2009; 3(4):133-36.

8 Haddan NE and Powderly WG. The Changing Face of Mycoses in patients with HIV/ AIDS. AIDS Read 2001; 11: 365-68,375

9 Martinez J and Temesgen Z. Opportunistic infections in patients with HIV and AIDS.

Fungal and parasitic infection J. Med. Liban 2006; 54:84-90.

10 Yang YL, Lo HJ, Hung CC, Li Y. Effect of prolonged HAART on oral colonization with candida and candidiasis. B.M.C Infect Dis 2006; 20: 6-8.

11 Favre B, Didmon $M$ and Neil S. Ryder NS. Multiple amino acid substitutions in lanosterol14a-demethylase contribute to azole resistancein Candida albicans. Microbiol 1999; 145: 2715-725.

12 Behzadi P, Behzadi E, Yazdanbod H, Aghapour R, Akbari Cheshmeh M, Salehian
In conclusion, there is a significant relationship between antiretroviral therapy, CD4+ counts, and the prevalence of candiduria among HIV patients. Therefore candiduria should be verified by obtaining a second specimen and appropriate therapy instituted after antifungal susceptibility teststo prevent systemic candidiasis amongthis population.
Omran D. Urinary tract infections associated with Candida albicans. Maedica. (Buchar) 2010; 5(4): 277-79.

13 Goetz LL, Howard M, Cipher D, Revankar SG.Occurrence of candiduria in a population of chronically catheterized patients with spinal cord injury. SpinalCord 2010; 48: 51-4.

14 Kauffman CA, Fisher JF, Sobel JD, Newman AC. Candida urinary tract infectionsDiagnosis. Clin Iinfec Dis 2011; 52 (Suppl 6): S452-56.

15 Kauffman CA. Candiduria.Clin Infect Dis 2005; 41 (Suppl 6):S371-76.

16 Fisher JF. Candida urinary tract infections Epidemiology, pathogenesis, diagnosis, and treatment: Executive Summary. Clin Infec Dis 2011; 52 (Suppl 6):S429-32.

17 Zarei-Mahmoudabadi A, Zarrin M, Ghanatir F, Vazirianzadeh B. Candiduria in hospitalized patients in teaching hospitals of Ahvaz. IJM 2012; 4 (4): 198-203.

18 Ayeni O, Riederer KM, Wilson FM, Khatib R. Clinicians' reaction to positive urine culture for Candida organisms. Mycoses 1999; 42:28589.

19 Wainer S, Cooper PA, Gouws H, Akierman A. Prospective study of fluconazole therapy in systemic neonatal fungal infection. Pediatr Infect Dis J 1997; 16:763-67.

20 Nucci M. Candiduria in hospitalized patients: a review. Braz J Infect Dis 2000; 4:168-72.

21 Weinberger M, Sweet S, Leiboviciy L, Pitlik SD, Samraz Z. Correlation between candiduria and departmental antibiotic use. J Hosp Infect 2003; 53: 183-86.

22 Dulawa J. Urinary tract infection-2003. Ann Acad Med Bialostoc 2004;49:182-84.

23 Achkar JM, Fries BC. Candida Infections of the Genitourinary Tract. Clin Microbiol Rev 2010; 23: 253-73.

24 Behzadi P, Behzadi E. The Microbial Agents of Urinary Tract Infections at Central Laboratory of Dr. Shariati Hospital, Tehran, Iran. Turk Klin Tip Bilim 2008; 28:445-49. 
25 Bukhary ZA. Candiduria: a review of clinical significance and management. Saudi J Kidney Dis Transpl 2008; 19:350-60.

26 Yang YL, Cheng MF, Chang YW, Young TG, Chi H, Lee SC, et al. Host factors do not influence the colonization or infection by fluconazole resistant Candida species in hospitalized patients. J Negative Results in BioMed 2008; 7: 12-14.

27 Esebelahie ON, Enweani IB, Omoregie R. Candida colonization in asymptomatic HIV

Patients attending a tertiary hospital in Benin City, Nigeria. Libyan J Med 2013; 8: 20322.

28 Paritpokee S, Hall G, Procop G. Rapid identification of yeast isolates using $\mathrm{BD}$ BBLTM CHROMagarTM Candida.A paper presented at the 105th General Meeting of the American Society for Microbiology. 2005;1-2.

29 Forbes BA, Sahm DF, Weissfeld AS. Laboratory Methods in Basic Mycology. Bailey and Scott's Diagnostic Microbiology. 12th ed. Mosby Elsevier. Philadelphia, USA; 2007 p. 629-717.

30 Clinical and Laboratory Standard Institute. Methods for antifungal disk diffusion susceptibility testing of yeast. Approved Guideline. 2nd ed. M44-A2. Vol. 29:17. CLSI, 940 West Valley Road, Suite 1400, Wayne, Pennsylvania, 19087-1898, 2009.

31 Abelson JA, Moore T, Bruckner D, Deville J, Nielsen K. Frequency of fungemia in hospitalized pediatric inpatients over 11 years at a tertiary care institution.Pediatrics.2005;116(1):61-7.
32 Binelli CA, Moretti ML, Assis RS, Sauaia N, Menezes PR, Ribeiro E. et al. Investigation of the possible association between nosocomial candiduria and candidaemia.Clin Microbiol Infect. $2006 ; 12(6): 538-43$.

33 Jain N, Kohli R, Cook E, Gialanella P, Chang $\mathrm{T}$, Fries BC. Biofilm formation by and antifungal susceptibility of Candida isolates from urine. Appl Environ Microbiol 2007; 73: 1697-703.

34 Nayman Alpat S, Özguneş I, Ertem 1. OT, Erben N, Doyuk Kartal E, Tözun M, et al. Evaluation of risk factors in patients with candiduria. Mikrobiyol Bul2011; 45: 318-24.

35 Kobayashi CC, de Fernandes OF, Miranda KC, de Sousa ED, Silva Mdo R. Candiduria in hospital patients: a study prospective.Mycopathologia. 2004; 158(1):4952.

36 Njunda AL, Nisagha DS, Assob JCN, Kamga HLN, Teyim P. Candidiasis in HIV and AIDS patients attending the Nylon Health District Hospital in Douala, Cameroon. TAF Prev Med Bull. 2011; 10(6):701-6.

37 Law D, Moore CB, Wardle HM, Ganguli LA, Keaney MG, Denning DW. High prevalence of antifungal resistance in Candida spp. From patients with AIDS. Antimicrobial Chem 1994; 34: 659-68.

38 Vuffray A, Durusel C, Boerlin-Patzoid F, Bille T, Glauser MD, Chave JP. Oropharyngeal candidiasis resistant to single-dose therapy with fluconazole in HIVinfected patients AIDS 1994; 8: 708-9. 